\title{
Do protesto à intervenção: socialização política, cidadania e insurgência em mobilizações estudantis de escolas públicas
}

BÓRIS MAIA

UNIVERSIDADE FEDERAL FLUMINENSE (UFF), NITERÓI/RJ, BRASIL

HTTPS://ORCID.ORG/0000-0002-7024-8605

\section{Introdução}

Desde as chamadas jornadas de junho de 2013, quando diversas manifestações de rua eclodiram em todo o Brasil tendo como bandeira as temáticas mais diversas, as passeatas, carreatas e os protestos de rua em geral parecem ter se legitimado definitivamente como um expediente frequente de reivindicações e lutas sociais no país, ocorrendo em associação estreita com o ativismo digital. Tais estratégias e repertórios de mobilização coletiva têm sido, inclusive, apropriadas e utilizadas extensivamente por grupos conservadores e de direita, historicamente mais refratários a elas, os quais foram decisivos para as mudanças políticas em curso nos últimos anos, desde o impedimento da presidente Dilma Rousseff até a chegada ao poder de Jair Bolsonaro (Gohn 2017; Guedes, Silva 2019).

Embora as lutas por educação oriundas de movimentos populares não sejam novidade, como Sposito (1993) já demonstrou em trabalho de referência sobre a temática, na última década as mobilizações coletivas que emergiram de contextos escolares, especialmente de escolas públicas e com os estudantes em papel de liderança, têm se destacado no que diz respeito à repercussão pública que alcançaram na chamada grande imprensa, ganhando adesão de muitos setores da sociedade não diretamente envolvidos com as causas e reivindicações em questão.

Dois movimentos são emblemáticos nesse sentido. O primeiro foi o criado no Rio de Janeiro em torno da manutenção da Escola Municipal Friedenreich, localizada dentro do complexo esportivo 
do Maracanã. As instalações dessa instituição de ensino seriam demolidas no início do ano de 2013, com sua remoção para outro bairro, em função de obras autorizadas pelo governo estadual para fins de realização no Brasil da Copa do Mundo de Futebol em 2014. Os estudantes e seus responsáveis iniciaram uma intensa mobilização, alinhada com a luta pela manutenção da Aldeia Maracanã, um coletivo indígena urbano instalado no antigo Museu do Índio - também parte do citado complexo -, que seria igualmente demolido (Pinto 2014).

No caso da escola, a indignação com a proposta de remoção devia-se ao fato de a entidade estar sempre nas primeiras colocações nas avaliações educacionais, além de ser considerada uma referência de inclusão, uma vez que nela eram desenvolvidas atividades de educação especial que levavam à instituição muitos estudantes que eram pessoas com deficiência ${ }^{1}$. Depois de aproximadamente nove meses de protestos de rua, ocupação da escola, audiências públicas, reuniões com políticos das esferas municipal, estadual e federal, a escola foi mantida e acabou tombada pela Câmara de Vereadores do Rio de Janeiro.

O segundo movimento teve expressão nacional e ficou mais conhecido como a ocupação de secundaristas de escolas públicas. Iniciado em São Paulo no final do ano de 2015, por ocasião de uma proposta do governo estadual de reorganização escolar, que previa o fechamento de cerca de noventa instituições de ensino e o remanejamento de quase trezentos mil alunos, o movimento de ocupação se alastrou por todo o país em 2016, sendo amplamente noticiado pelos órgãos de imprensa e encontrando respaldo em meio à população, especialmente entre intelectuais e artistas.

No caso de São Paulo, o movimento dos estudantes provocou a renúncia do secretário de educação Herman Voorwald, a derrubada da popularidade do governador Geraldo Alckmin e a revogação do projeto de fechamento das escolas (Campos, Medeiros, Ribeiro 2016). Em outros locais do país, pautas diversas mobilizaram os estudantes, sendo as principais a reforma nacional do ensino médio, promovida pelo governo de Michel Temer a partir de uma medida provisória (MP 746/2016) e o enfrentamento às iniciativas do movimento "Escola Sem Partido".

O movimento de ocupação escolar dos estudantes secundaristas foi objeto de diversos trabalhos acadêmicos, seja analisando as mobilizações no caso paulista (Campos, Medeiros, Ribeiro 2016; Catini, Mello 2016; Corti, Corrochano, Silva 2016), seja as ocorridas em outros estados do país (Pinheiro 2017; Barbosa, Brum 2018; Carvalho, Medaets, Mézié 2019; Morais, Sordi, Fávero 2019). Além do atendimento a algumas das reivindicações mais concretas e objetivas do movimento, sobretudo no caso de São Paulo, de modo geral, tais trabalhos enfatizam a dimensão formativa que tal experiência provocou nos estudantes, os quais tiveram suas subjetividades transformadas após a vivência das ocupações escolares.

Se as aulas regulares foram interrompidas e os conteúdos curriculares ficaram em segundo plano, o aprendizado no período das ocupações se caracterizou por um intenso envolvimento com atividades políticas (organização de manifestações de rua, promoção de debates, articulação entre as escolas ocupadas, busca de apoios externos para o movimento, diálogo e negociação com secretários de educação, diretores e professores) e com a gestão do comum (limpeza da escola, organizar e preparar os alimentos

1 Em 2016, seria a escola com a melhor nota da rede pública do Rio de Janeiro no Índice de Desenvolvimento da Educação Básica (IDEB). 
arrecadados, planejar as atividades da semana, etc.). Em suma, o saldo positivo mais enfatizado sobre as ocupações escolares dos secundaristas foi o aprendizado cívico proporcionado aos sujeitos envolvidos no processo de mobilização coletiva.

Este trabalho trata justamente de mobilizações estudantis em escolas públicas a partir de um caso acompanhado por mim no ano de 2013. As mobilizações estudantis são entendidas aqui como formas de ação coletiva, as quais se caracterizam por uma atuação concertada em função de uma intenção consciente (Cefaï 2007). Apoiando-me em pesquisa etnográfica, pretendo apresentar todo o processo de mobilização dos estudantes de uma escola estadual do Rio de Janeiro ao reivindicarem melhorias em sua instituição. Busco analisar o processo de socialização política em jogo e o significado de tais demandas na atual conjuntura sociopolítica brasileira, tomando como referência a dinâmica que se estabeleceu ao longo do processo entre estudantes, professores, diretores e gestores, assim como o desfecho do caso analisado. Os dados são oriundos de uma pesquisa que realizei durante onze meses no ano de 2013, que investigava o processo de construção da autoridade de professores em escolas públicas (Maia 2019).

O foco do artigo, portanto, volta-se para o modo como a experiência escolar proporciona o aprendizado da vida em comum para os estudantes. Resende (2008) destaca que essa é uma das atribuições essenciais da instituição escolar desde a modernidade. $\mathrm{O}$ autor conceitua tal tarefa como "socialização política", que consiste no "trabalho qualificador (...) feito para preparar os alunos para enfrentarem o mundo, participando no governo dos assuntos da cité política" (Resende 2008: 16). Identificando uma baixa inclinação para o envolvimento político na população juvenil portuguesa e seu relativo desinteresse na participação pública, Resende chama a atenção para as implicações negativas de tal comportamento dos jovens para a sociedade portuguesa no que concerne à permanente construção da democracia no país, já que o engajamento dos cidadãos é uma das características que definem o regime democrático. A continuidade desse regime político está relacionada com a obrigação moral dos cidadãos de defenderem a qualidade dele, por meio do cumprimento de suas obrigações e da disposição de se exporem publicamente nas discussões, debates e manifestações públicas.

A escola, por sua vez, é tomada neste trabalho como uma "arena pública", nos termos de Cefaï (2002), construto teórico que visa a dar conta da dinâmica que os debates públicos adquirem nas sociedades modernas. Tal "arena” evidencia a dimensão dramatúrgica dos confrontos públicos e busca superar concepções mais deterministas da ação social, que têm como chave explicativa as condições estruturais dos agentes. Pensando a escola como "arena", busca-se salientar o lugar que a instituição ocupa como um fórum de discussão pública, onde as formas de agir coletivamente são aprendidas e reinventadas, mobilizando os atores a partir das suas experiências relacionadas aos diferentes cenários em que se movem.

A seguir, passo à descrição etnográfica do processo de mobilização estudantil que se sucedeu ao longo do trabalho de campo que realizei durante um ano letivo, em uma tradicional escola pública de uma cidade pertencente ao Estado do Rio de Janeiro. Posteriormente, apresentarei algumas considerações acerca do que tal processo pode nos revelar sobre mobilizações coletivas de estudantes e a reivindicação de direitos de cidadania no contexto contemporâneo brasileiro. 


\section{Uma conjuntura de crise: insatisfação e mobilização dos estudantes}

No início do ano de 2013, voltei a fazer trabalho de campo no CECS, uma escola pública localizada em uma cidade do Estado do Rio de Janeiro, que eu já havia frequentado como pesquisador durante os anos de 2010 e 2011, por ocasião da realização de um estudo sobre conflitos envolvendo religião em âmbito escolar (Maia 2014) ${ }^{2}$. Diferentemente da conjuntura da pesquisa anterior, o clima agora era de insatisfação com as condições dessa instituição de ensino.

A escola atendia cerca de 1.900 alunos, sendo a maior destes pertencentes ao ensino médio. Contava ainda com 137 professores e 21 funcionários. Localizada em um bairro eminentemente residencial, de classe média à média alta, próximo à região central da cidade, a CECS é cercada por edifícios, pequenos estabelecimentos comerciais e por dois dos campi da universidade pública sediada na cidade. O bairro também abriga três favelas, de onde parte dos estudantes que compõem o público da escola era oriunda. Mas o perfil socioeconômico do alunado revelava-se variado. Havia também discentes que moravam em lugares mais distantes - alguns em bairros afastados da cidade, outros em municípios vizinhos -, porém, optavam por estudar na escola em função da alta qualidade que atribuíam a ela. Uma terceira parcela dos alunos era formada por moradores de classe média do próprio bairro da escola, muitos egressos de escolas particulares que, por razões diversas, optaram por fazer o ensino médio em uma instituição pública.

Logo nos primeiros dias de aula, em fevereiro, enquanto eu fazia algumas notas de campo sentado no banco da antessala da direção, um grupo de nove alunos do $2^{\circ}$ ano se aproximou reclamando da escola. Duas alunas sentaram-se bruscamente ao meu lado e ficamos espremidos três pessoas no banco, enquanto o restante do grupo ficou em pé, frente a nós. Jonas, o único homem do grupo, explicava que tinha acabado de recusar uma proposta da diretora-geral para que sua turma mudasse de sala. Ele disse: "Ah, meu bem, muito obrigado, mas tirar a gente daquela sala para botar em uma menor, não rola. Falei isso pra ela”. As demais alunas riam da forma como Jonas narrou o episódio e fizeram coro à reclamação dele.

Perguntei ao grupo de que turma eram e eles disseram " 2 C". "E qual é a sala?", continuei. "É a penúltima do corredor do outro prédio", disse umas das meninas. Eles, então, começaram a reclamar comigo da sala: "Vai lá pra você ver. Não tem nem ventilador, não tem um giz e quadro para o professor escrever". Outra menina, do meu lado, completou: "E pra poder entrar um, tem que sair outro". As turmas terminadas em C (1C, 2C, 3C) eram consideradas as "piores da escola", porque nelas se concentrava a maioria dos alunos "repetentes" e considerados "indisciplinados", que, em virtude disso, eram colocados nas piores salas.

Jonas continuou a se queixar: "Ficar lá naquele inferno, eu não! Não sou bicho! A professora vai querer dar aula no pátio, mas eu não vou assistir. Eu hein... não dá nem pra escrever nada”. Disse em

2 Como de praxe nos trabalhos antropológicos, o nome da escola e os nomes verdadeiros dos interlocutores desta etnografia foram alterados para resguardar a identidade de todos. Ademais, para que a instituição de ensino não seja identificada, omito também a cidade em que a pesquisa foi realizada. 
seguida: "A gente tem que reunir a turma, fazer uma greve, todo mundo botar um pano na boca, fazer alguma coisa". As meninas concordaram com ele, rindo de sua forma desinibida e espalhafatosa de falar. Uma delas afirmou: "É isso, pago meus impostos, quero pelo menos uma sala".

A que se sentava do meu lado esquerdo, espremendo-me no banco, assinalou: "Não dá, a gente vem pra escola e nunca tem aula”. Jonas me falou que eles já estavam "liberados" - era por volta de 08h40min. Outra aluna asseverou: "Assim não dá mesmo. Eu moro longe, acordo 5 horas da manhã todo dia para estar aqui e não tem aula". Eles começaram a discutir a possibilidade de fazer uma "greve", isto é, não irem mais à escola enquanto continuassem naquela sala. Uma das alunas disse que sempre teria pelo menos três pessoas que iriam furar. "Mas três pessoas não dá pra ter aula", replicou Jonas. Ele chamou as colegas para o pátio, onde pretendiam discutir a situação com o restante da turma.

A antessala da direção era um lugar da escola estratégico para acompanhar a crise que o colégio vivenciava. No início do ano, além dos alunos, muitos pais iam à escola para falar com os diretores ou à secretaria levar documentos para regularizar a matrícula, entre outras coisas. A antessala era onde todos esperavam até serem atendidos e por onde passavam depois de tê-lo feito. Assim, diariamente, era possível ali ouvir e travar conversações com os pais e alunos sobre a percepção negativa que compartilhavam em relação à situação da escola.

Em um dos dias, enquanto esperava para assistir aos dois últimos tempos de matemática na 3A, fui para a antessala com Bruno, um estudante que pretendia falar com alguém da direção. Bruno foi um dos meus interlocutores mais próximos durante a pesquisa. Já o conhecia há dois anos, quando fiz uma investigação anterior na escola. O diretor-adjunto Flávio era a única pessoa que estava na direção e, além de Bruno, vários alunos esperavam para falar com ele. A diretora geral, Sandra, não havia ido à escola no período da manhã.

Uma aluna saiu da sala da direção, em passos rápidos, com o semblante aparentando irritação, dizendo: “Filho da puta!”. Duas alunas também saíram de lá reclamando. "Vou quebrar tudo isso aqui!", disse uma delas. "Eu hein, escola muito ruim", acrescentou a outra. Em seguida, um aluno que pretendia falar com Flávio foi persuadido por outro, que acabava de sair da sala da direção, de não o fazer no momento: "Mó bagunça que está ali. Não tem nem como a gente falar com ninguém”.

Como forma de protesto, os alunos começaram a colar folhas de papel nas paredes dos corredores das salas de aula. Nas folhas, dizeres como "Queremos respeito" e "Isso é palhaçada", escritos à mão com caneta hidrocor pelos próprios estudantes, tornavam evidente a insatisfação deles com a escola em que estudavam.

As demonstrações de insatisfação com as condições da instituição de ensino não eram exclusividade dos alunos. Os docentes e funcionários também a expressavam pelos corredores, durante as aulas e na sala dos professores, sem qualquer discrição, como o professor de sociologia que chegou nesse espaço se queixando da bagunça da escola. Contou-me que tinha sido convidado para ficar na secretaria, pois o setor estava sem funcionário, mas recusou a oferta. Ele me chamou para ouvir a ex-diretora, que, depois de dizer que a escola estava no seu "pior momento", contava na sala dos professores sobre a época de sua gestão, quando ouviu um dos representantes da Secretaria de Estado de Educação (SEEDUC) dizer que sua meta era acabar com o CECS. "E conseguiu”, completou. 
Inflamados pelas queixas de seus filhos, os pais também começaram a ir à escola manifestar seu desagrado com as condições da instituição. Uma mãe foi acompanhada de sua filha reclamar que o professor de história havia dado uma prova sem que os alunos tivessem recebido o livro didático. O zelador as recebeu no portão e disse que não tinha ninguém para atendê-las. A mãe começou a se queixar dos problemas da escola para o zelador, que ouvia fazendo alguns comentários no sentido de mostrar que entendia as razões, mas que não poderia ajudá-la na solução do problema. A mãe continuava: "Do jeito que está essa escola aqui, é escola pra bicho, não é escola pra gente!”. Depois de ver que não conseguiria atendimento, mãe e filha deixaram a instituição. Outra das mães, também acompanhada da filha, apareceu no portão querendo entrar, dizendo que ia pedir a transferência da menina para outra escola. Presenciei diversas vezes, sobretudo no início do ano, essa rotina de reclamos.

As frequentes reclamações de diferentes atores no ambiente da escola vinham sendo administradas com dificuldade pela direção. Salas superlotadas e sem ventilação, alunos sem turma, matrículas canceladas, turmas sem professor, entre outras razões, fizeram com que os estudantes se organizassem para reivindicar melhores condições de ensino. Os alunos do grêmio decidiram organizar o que chamaram de "protesto", com o objetivo de chamar atenção das autoridades superiores e da mídia para o que entendiam ser um descaso com a tradicional escola da cidade.

Até que decidissem por uma mobilização para organizar o protesto, o grêmio estudantil não tinha uma atuação muito presente. Na verdade, confundia-se com a rádio da escola. A instituição tinha uma rádio organizada pelos alunos, que tocava músicas na hora do recreio pelos alto-falantes. Os estudantes que eram da rádio - em sua maioria de turmas de $2^{\circ}$ e $3^{\circ}$ anos do ensino médio - ganhavam prestígio, pois controlavam as músicas que tocavam no recreio, assim como podiam dar recados pelo sistema de som, coisas que despertavam o interesse (e provocavam conflitos) entre os jovens no cotidiano escolar.

Muitos alunos do grêmio também participavam da rádio, fazendo com que o espaço da sala desta última acabasse servindo como lugar de discussões espontâneas que surgiam sobre questões relativas ao primeiro. Esses discentes não tinham quaisquer experiências prévias de militância e passaram a considerar a criação de um grêmio estudantil depois que um grupo da União Brasileira de Estudantes Secundaristas (UBES) foi à escola para estimular a organização política dos alunos. Um coletivo que já se reunia em torno da rádio resolveu fundar o grêmio, sem que tenha havido eleição e apenas com a proposta geral de lutar pelos direitos dos estudantes. O grêmio não tinha sequer uma sede própria, então as reuniões não tinham local exato para ocorrer e às vezes aconteciam sem uma prévia combinação. Além da sala da rádio, os corredores e o pátio eram os locais onde o pessoal do grêmio se reunia, inclusive para organizar o protesto que decidiram realizar.

Pude acompanhar de perto esse processo de mobilização dos alunos. Numa quinta-feira, quando saí da sala dos professores, onde procurava por alguns dos docentes das turmas 3A e 3B para pedir permissão de modo a assistir às suas aulas, Bruno me chamou no corredor: "Você vai embora ou vai ficar por aqui?". "Vou ficar", eu disse. "É porque a gente vai passar em sala para falar do protesto da escola que a gente vai fazer segunda". Juntei-me ao grupo. Eles foram primeiro nas salas de primeiro ano, no andar de baixo. 
Sete ou oito alunos do grêmio estudantil se dividiram em duplas ou trios para passar nas salas. Eles batiam na porta, caso a turma estivesse em aula e pediam ao professor para dar o recado. Não entrei com eles nas salas, fiquei apenas acompanhando da porta. Um dos estudantes falava das condições desses espaços físicos. Mencionou que em sua sala não tinha ventilador, com cinquenta pessoas na turma e não havia cadeira para todos os alunos. Disse que era importante todos comparecerem na segunda-feira. Depois que o estudante terminou, Bruno falou alto, com o braço direito levantado e o punho cerrado: "É isso aí pessoal, vamos mudar a escola! Segunda-feira todo mundo aqui". Os ouvintes pareciam receptivos à mensagem levada por seus colegas do grêmio.

O grupo de alunos saiu das salas do $1^{\circ}$ ano e foi para a antessala de entrada da escola conversar com as duas inspetoras que estavam no balcão. A inspetora começou a reclamar da postura deles, dizendo que não podiam ficar entrando nas salas sem autorização. Eles disseram que os professores das turmas os estavam apoiando. "A gente tem o direito de protestar", disse um. Outra aluna afirmou: "Nós estamos exigindo os nossos direitos". "Uma coisa é protesto, outra é baderna”, retrucou a inspetora. "Estamos querendo melhorar a escola. Você acha bom ter só três inspetoras no colégio?”, João perguntou. Ela balançou a cabeça negativamente. "Então, é por isso”, reforçou. Bruno sinalizou: "Não tem um médico aqui". "Ah, você quer médico, é?", respondeu ironicamente a inspetora. "Claro, tem muita gente que passa mal aqui todo dia", respondeu.

No dia seguinte, sexta-feira - último dia de aula antes do "protesto" - dois alunos do grêmio, João e Thayla, foram à sala dos professores pedir contribuiçóes em dinheiro para ajudar na manifestação de segunda-feira. João disse que seria um protesto "totalmente pacífico" e que a ideia era os estudantes ficarem na entrada da escola, sem assistir às aulas. Uma das professoras pediu ironicamente para que eles fizessem a manifestação na terça-feira, dia em que daria aula (pois assim seria cancelada).

Alguns docentes sugeriram aos alunos que entrassem em contato com a imprensa. João disse que já tinham confirmado a presença de emissoras de televisão e do jornal local da cidade. Explicou que tinha uma página no Facebook com várias fotos e que estava organizando um dossiê com o material. Citou alguns dos problemas da escola, como as turmas superlotadas e a sala da turma $2 \mathrm{C}$, na qual faltavam ventiladores. A professora de português falou que era importante "exigir uma merenda boa e segurança”. Vários professores deram contribuições. Um docente de matemática entregou dez reais aos alunos, dizendo: "Tem que protestar mesmo”. Reclamou dos livros didáticos “jogados” na sala da coordenação, da "imundície", do "calor". "É claro que a direção tem responsabilidade nisso tudo", completou. Thayla me falou que eles já tinham comprado mais de duzentos narizes de palhaço.

Foi Bruno quem primeiro me avisou sobre a ideia de fazer o protesto. A proposta surgiu, inicialmente, depois de uma reunião com a diretora-geral, logo no primeiro dia de aula. Com os crescentes problemas que a escola foi acumulando durante as semanas letivas iniciais, a ideia foi encontrando respaldo dos demais alunos e professores, até se tornar realidade em meados de março, numa segunda-feira, exatamente um mês depois de as aulas terem começado. 


\section{$\mathrm{O}$ ápice da mobilização: o protesto}

Passado um mês exato do início das aulas, havia chegado o dia da manifestação organizada pelos alunos do ensino médio. Era uma segunda-feira, 18 de março de 2013, as nuvens tomavam conta do céu cinzento e o sol não dava indícios de aparição. Cheguei à escola por volta de seis horas e 45 minutos da manhã. Muitos alunos já estavam nos arredores e no pátio de acesso aos prédios da instituição, em sua maioria ocupando-se dos preparativos para a manifestação - também chamada por eles de "protesto" - que visava a reivindicar melhorias nas condições de ensino da escola. Logo avistei Luana, com quem fui falar. Ajoelhada no chão, cercada por tintas, canetas e pincéis, ela escrevia em um dos cartazes que elaborava com algumas de suas colegas. Em nossa breve conversa, Luana me disse que dois funcionários da SEEDUC estavam na escola tentando evitar o protesto.

A chuva que já se anunciava começou a cair, ainda branda, alguns minutos depois das sete horas, o que fez com que a maioria dos alunos buscasse refúgio na parte coberta do pátio de acesso à escola. $\mathrm{A}$ entrada para o prédio da instituição, no entanto, estava bloqueada por dois alunos, que se revezavam, impedindo o ingresso dos demais ao interior do prédio, com exceção dos professores e funcionários ${ }^{3}$. Felipe distribuía apitos e narizes de palhaço a todos. “Quer um?”, perguntou oferecendo-me um dos narizes redondos e vermelhos. Estendi a mão e peguei o pequeno adereço.

Um carro de uma rede de televisão aberta estava estacionado em frente à escola e, entre o carro e o portão da escola, a repórter conversava com os alunos sobre as razões da manifestação. Quando a câmera foi ligada, muitos deles se aglomeraram em torno da repórter, segurando cartazes e apitando, a maioria caracterizada com os narizes de palhaço. Alguns transeuntes que passavam pela rua paravam momentaneamente para olhar a cena atípica que presenciavam naquele início de manhã. Aos poucos, a presença dos estudantes foi aumentando e eles passaram a ocupar uma parte maior da rua, o que começou a provocar um início de engarrafamento nas proximidades.

Mesmo com a chuva que ia ficando mais intensa, um grande número de alunos permanecia na rua protestando. Aqueles que iam chegando para as aulas aderiam à manifestação que, depois de meia hora de iniciada, já provocava uma lentidão significativa no trânsito. Os estudantes pediam aos motoristas que passavam que buzinassem, como forma de demonstrar seu apoio a eles. Muitos retribuíam o pedido, provocando ardorosos gritos de agradecimento; outros, em menor número, passavam reclamando da "baderna" após abaixarem o vidro do carro, ao que os alunos respondiam com vários xingamentos, além de vaias e gestos obscenos.

Os funcionários da SEEDUC presentes no local, um homem e uma mulher, tentavam intervir na situação. A mulher dizia a um dos alunos do grêmio estudantil que já havia sido agendada uma conversa e que a manifestação não era necessária. $\mathrm{O}$ estudante, um pouco intimidado, negava a informação. O homem, por sua vez, queria que os discentes interrompessem a manifestação e entrassem para uma conversa no auditório, mas eles não se mostravam dispostos a aceitar a proposta. A ausência da

\footnotetext{
3 Nem todos os estudantes eram favoráveis ao protesto. Alguns pretendiam ter aulas no dia, mas acabavam tendo a entrada no prédio da escola bloqueada por estudantes que organizavam a manifestação. No entanto, isso não causou maiores problemas, pois a maioria dos alunos foi à escola para participar do protesto.
} 
diretora-geral, Sandra, era cantada pelos alunos, que com palmas marcavam o ritmo: "Ô diretora, cadê você? Assume o erro na TV! Ô diretora, cadê você? Assume o erro na TV!".

A diretora-geral, Sandra, chegou por volta de oito horas da manhã e ficou conversando com os funcionários da SEEDUC no pátio de acesso, onde alguns alunos ainda se resguardavam da chuva. Flávio, o diretor-adjunto, foi para a rua e tentou colocar os estudantes para dentro da escola, ordenando que fossem para o pátio. Os alunos começaram a vaiá-lo e não entraram. A repórter, percebendo que Flávio ocupava um cargo na direção, foi até ele, com o microfone e a câmera ligada, cobrar explicações sobre a situação. Fugindo das perguntas, Flávio voltou ao pátio, seguido pela repórter e pelo cinegrafista e apontou para a diretora-geral, dizendo: "Ela é a diretora-geral. Ela é a diretora-geral".

A repórter, então, começou as perguntas a Sandra. Depois de questionar a diretora sobre as condições da escola, fez uma última pergunta: “Seu filho estuda numa escola assim?”. A diretora respondeu de forma veemente: "Meus três filhos são alunos de escola pública!". Os estudantes, que já rodeavam a diretora-geral enquanto a repórter a entrevistava, gritaram em coro: "Mentirosa! Mentirosa! Mentirosa!". A cena seria veiculada mais tarde em um popular telejornal do Estado.

Em determinado momento do protesto, os alunos decidiram ocupar toda a extensão da rua, impedindo a passagem dos carros e ônibus. Uma viatura da polícia chegou logo depois, reabrindo parte da via. Com o celular em mãos, eu tirava diversas fotos enquanto acompanhava a manifestação. Muitos posavam para que eu os fotografasse, quando em seguida iniciávamos conversações rápidas sobre as razões do protesto. Três cartazes levados pelos estudantes foram posicionados à frente do grupo que se preparava para seguir em passeata, com os dizeres: "Na sala de aula é que se muda uma nação", "Aos que pensam que somos palhaços, lembrem-se que somos o futuro desse país” e "Melhorias já!”.

Depois de mais de uma hora fazendo o protesto em frente à escola, os alunos, orientados pelos membros do grêmio estudantil, puseram-se a marchar pelas ruas da cidade em direção a outra escola pública estadual, o LOTUS, que, como o CECS, era uma das maiores e mais renomadas instituições de ensino públicas da cidade. Durante o trajeto, a chuva aumentou bastante, mas não dispersou os animados alunos, que seguiam com seus cartazes (já se desfazendo depois de molhados), narizes de palhaço e apitos, os quais, junto com as palmas e um ou outro tamborim, somavam-se ao som dos gritos e palavras de ordem. Quando chegaram ao LOTUS, depois de percorrer cerca de 2,5 km, sob a chuva ininterrupta desde o início, os manifestantes começaram a fazer pressão para que a diretora do LOTUS deixasse os alunos saírem da escola. A larga escada que dava acesso ao portão dessa instituição estava tomada pelos discentes do CECS, que gritavam e batiam no portão: "Uh, abre a porta! Uh, abre a porta! Uh, abre a porta!”.

A diretora, no portão principal, junto com um porteiro, negava-se a liberar os alunos. Foi então que apareceu a mãe de um dos estudantes do LOTUS, que, desavisada da manifestação, foi à escola resolver alguma questão sobre a matrícula de seu filho. Os alunos abriram espaço para que a mulher chegasse até o portão. Depois de explicar sua situação diretamente para a diretora através dos caixilhos, a responsável teve sua entrada permitida e o portão foi entreaberto para que apenas ela adentrasse o prédio. Os alunos aproveitaram o momento e forçaram a passagem, escancarando-a rapidamente. Percebendo a proeza de seus colegas do CECS do lado de fora, os alunos do LOTUS avançaram em 
direção ao portão, ignorando a tentativa da diretora de contê-los, saindo do prédio às pressas. Seguindo pela escada abaixo, os discentes do LOTUS alcançaram o centro da manifestação, onde foram recebidos pelos colegas do CECS com euforia, a eles se misturando e junto deles celebrando o êxito da "fuga".

Unidos, os alunos do CECS e do LOTUS tomaram o rumo da sede regional da SEEDUC, que distava cerca de 800 metros de onde estavam. Chegando lá, a entrada no prédio foi a princípio negada pelos seguranças de plantão na portaria. Depois de uma negociação com uma das representantes da Secretaria, foi acordado que uma comissão de trinta alunos de cada escola seria recebida para uma reunião. Tal anúncio foi feito, na portaria do prédio, por um estudante do LOTUS. Caberia aos representantes do grêmio das duas escolas a seleção de quem participaria da reunião.

Como a maioria dos manifestantes desejava participar da reunião, produziu-se uma densa concentração em frente à portaria da Secretaria, de onde alguns membros do grêmio das escolas chamavam pelo nome os escolhidos. Depois de muito aperto e alguns empurrões, consegui chegar ao grupo da frente. Levantei o braço, como muitos dos que queriam entrar faziam para chamar atenção dos alunos do grêmio que faziam a seleção. Um aluno do LOTUS foi quem me viu e perguntou: "Você é professor?". Respondi que era da universidade e fazia uma pesquisa no CECS. "Vem, entra, entra", disse ele me dando o passaporte. Subi com os estudantes, de elevador, até o andar do prédio onde a reunião seria realizada. Era uma sala cuja capacidade atenderia com sobra os sessenta alunos requisitados, com uma mesa extensa na frente, onde alguns representantes da Secretaria já aguardavam sentados.

Depois de acomodados os alunos, Dalva, a representante da SEEDUC de mais alta hierarquia dentre os presentes, iniciou a reunião. Sua fala foi breve e tentava justificar os problemas que afligiam as escolas naquele início de ano letivo. O clima da reunião era pouco amistoso. Dalva falava com um tom enérgico, que soava agressivo em certos momentos. Outro representante da Secretaria se manifestou em seguida, informando os procedimentos que estavam sendo tomados. Insatisfeito com as explicações dos representantes, um aluno murmurou: "tão de brincadeira". Ouvindo o murmúrio, o representante da SEEDUC foi enfático: "Eu não estou aqui brincando de trabalhar". O discente imediatamente respondeu, no mesmo tom: "Nem a gente brincando de estudar".

A palavra foi dada aos estudantes, que deveriam se inscrever para ter o direito à fala. Foram muitas as reclamações, mas elas se concentravam em duas questões que eram comuns aos alunos das duas escolas, a saber, a queixa sobre o tratamento que lhes era dispensado pela equipe técnico-pedagógica $^{4}$ e a condição de precariedade de pessoal e das instalações ${ }^{5}$. Diante das queixas, os representantes da Secretaria buscavam minimizar os conflitos que os estudantes expunham. Depois de um destes ter reclamado das condições físicas de sua sala de aula, um representante da Secretaria disse que no serviço público isso era comum. A resposta não agradou o aluno, que retrucou: "Não acho nada comum! O senhor trabalha com teto caindo?! O senhor trabalha com lâmpada quebrada?!”.

4 Os alunos disseram que: "não há diálogo"; "falta transparência, ninguém informa as coisas"; "quando não tem professor, os alunos são liberados e ninguém dá nenhuma satisfação"; "é preciso ter uma comunicação melhor"; "a inspetora trata os alunos com um desdém”; "ela [inspetora] trata a gente como bicho".

5 Sobre isso, falaram: "tem poucos funcionários”; “os ventiladores não funcionam, é uma sauna lá dentro”; “tem muito lixo, a quadra está cheia de entulho"; "estamos com falta de professor"; "o banheiro está todo quebrado"; "na minha sala não tem cadeira pra todo mundo". 
A insatisfação dos alunos parecia evidente. Em determinado momento da reunião, Thayla, uma das discentes do CECS, acenou-me e apontou uma cadeira próxima de onde estava, dizendo: "Senta aqui". Atendi a seu chamado e fui até a cadeira indicada. Assim que me sentei, a aluna pediu que eu chegasse próximo a ela e sussurrou no meu ouvido: “Que enrolação isso aqui hein!". Balancei levemente a cabeça, concordando. A Secretaria propôs aos estudantes reuniões periódicas para que a pauta de reivindicações fosse discutida. Foi requisitado aos estudantes que discutissem entre si quem participaria das reunióes e as datas para realizá-las. Após mais de duas horas na Secretaria, o encontro foi encerrado. Os alunos comentavam sobre o desfecho. Um deles disse: "É, enrolaram, enrolaram e não sai nada”. Felipe manifestou-se no mesmo sentido, dizendo que os funcionários da Secretaria ficaram "dando desculpas".

Ao final, quando fui pegar um copo de água no bebedouro, deparei-me com Sandra, a diretora-geral do CECS, que foi fazer o mesmo. “Tudo bem?”, cumprimentei-a. "Não sei se está tudo bem não...”, respondeu ela. Não estava mesmo. Sandra acabou exonerada da direção do CECS e, desde então, nunca mais a reencontraria.

\section{“Habemus Papam”: a intervenção}

A repercussão do protesto foi significativa na cidade. O mais importante jornal impresso local publicou uma matéria sobre o episódio no dia seguinte à manifestação. Na televisão, a mobilização rendeu uma matéria de mais de sete minutos em um conhecido noticiário de uma emissora aberta, exibida poucas horas depois de terminado o protesto. Essa matéria foi postada logo em seguida na página da emissora na internet, onde podia ser assistida na íntegra, o que fez com que os alunos e professores a divulgassem entre si por meio das redes sociais.

A reportagem trazia imagens dos alunos percorrendo as ruas da cidade com cartazes e narizes de palhaço. "O centro de (...) parou para a passagem dos caras pintadas", dizia a narração enquanto tais imagens eram mostradas ${ }^{6}$. Um integrante da equipe televisiva entrou na escola com uma câmera escondida e filmou alguns dos problemas de que os estudantes se queixavam, como paredes descascando e com infiltrações; bebedouros sem água; banheiros sem descarga, com portas inutilizadas e pichadas; salas de aula com o quadro negro danificado, janelas quebradas, pilhas de carteiras deterioradas empilhadas em um dos corredores e dezenas de livros didáticos jogados no espaço da antiga coordenação de turno.

O dia seguinte à manifestação foi bastante conturbado na escola. Nenhum dos integrantes da Direção apareceu na instituição, reforçando a tese da exoneração que já vinha circulando em forma de boato desde a semana anterior. Logo que cheguei, perguntei à inspetora sobre a diretora. Ela respondeu sussurrando e escondendo a boca com a mão que a diretora tinha sido exonerada. No momento em que falava com a inspetora, duas alunas vieram abordá-la. Elas queriam tirar cópia de uma folha de exercícios em algum lugar próximo, pois a copiadora da escola não estava funcionando. A inspetora

6 Os alunos não estavam com o rosto pintado. Foi apenas uma analogia dos jornalistas em referência às manifestações do período "Fora Collor", no início dos anos noventa, em que coletivos estudantis reivindicavam o impeachment do presidente da república Fernando Collor de Mello. 
não permitiu que elas saíssem. As meninas argumentavam que a folha seria usada naquele dia em uma das aulas, mas a inspetora manteve sua posição. A menina então falou: "Essa escola é uma bagunceira, ninguém respeita ninguém”. E voltaram para a sala.

Alguns pais, depois da repercussão da manifestação noticiada na imprensa, resolveram ir até a escola para cobrar explicações. Ao serem informados de que os diretores não estavam na escola, começaram a reclamar pelo fato de não ter ninguém para atendê-los. Uma das mães disse: "Um absurdo. Se acontece alguma coisa na escola, quem vai resolver? Não tem diretor, nem diretora”.

A possível exoneração de Sandra, há três meses no cargo máximo da escola, era o assunto da sala dos professores. Uma docente recém-chegada à instituição, ouvindo a conversa de três outros colegas na sala, perguntou se já tinham escolhido a nova diretora. A instabilidade no cargo de diretor-geral virou motivo de brincadeiras frequentes nesse espaço. Um dos professores de matemática, Wilson, anunciou a seus confrades que estava fazendo um novo "bolão" para saber quem seria o novo dirigente da escola e por quanto tempo conseguiria permanecer no cargo. Esse diretor-geral seria o quarto a ocupar o cargo desde agosto de 2010. Gerson, um antigo docente de educação física, assim que entrou na sala, disse: "é aqui que está sendo a reunião para a decisão do novo Papa?". Depois de alguns risos, uma professora comentou: "é, mas se sair uma fumaça negra, sai correndo, porque é incêndio".

A referência ao Papa e à fumaça negra não foi ao acaso. Na mesma semana acontecia o conclave na cidade-Estado do Vaticano, onde seria decidido o sucessor do Papa Bento XVI, que havia renunciado ao cargo em fevereiro de 2013. Também naquele período havia ocorrido um pequeno incêndio na escola. Eu estava na sala da direção quando aconteceu o incidente. Duas alunas entraram na sala da direção com roupas de educação física, reclamando que o banheiro estava "lotado, a maior confusão" e que depois iam dar advertências para elas por estarem com "aquela roupa". A diretora pediu para aguardarem, pois estava pegando fogo em um disjuntor da escola e ela precisava resolver a situação antes de qualquer coisa. As meninas insistiram na queixa que faziam. A diretora perdeu a paciência e, deixando a sala, disse: "Pois é, tomara que pegue fogo e morra todo mundo queimado". As meninas, sem ter mais com quem falar, saíram também insatisfeitas.

Os alunos, protagonistas da manifestação, lembravam entre si os momentos vividos no dia anterior. Encontrei no corredor com Thayla, João e Diana, três membros do grêmio que tiveram um papel ativo na organização do protesto. Perguntei se eles tinham visto a matéria que passou na televisão e os três disseram que sim. Falei para Diana que ela apareceu várias vezes com a faixa que carregava. "É, eu sei”, disse ela rindo. João, orgulhoso, comentou que também havia aparecido bastante. Embora reivindicassem uma sala à direção, o grêmio estudantil, como já dito, não tinha uma sede própria, então era comum que fizessem reuniões nos corredores e no pátio da escola.

Por mais que os funcionários da SEEDUC não admitissem publicamente o fato, sobretudo depois da repercussão dada aos problemas pela manifestação, era claro que já estavam em busca de um substituto para Sandra. Depois de passarem por um concurso público específico para o cargo de diretor, os aprovados assumiam a direção de uma escola indicada pela SEEDUC, estando sujeitos à exoneração 
por parte do mesmo órgão. Quando isso ocorre, o que não era coisa infrequente, costuma-se dizer no universo escolar que houve uma "intervenção" e o novo diretor assume, então, como um "interventor" 7 .

Macedo, um popular professor de biologia, foi anunciado como novo diretor-geral do CECS numa quinta-feira, 21 de março, assim como as duas diretoras-adjuntas que comporiam com ele a nova direção. Aprovado no mesmo processo seletivo da SEEDUC para o cargo de diretor-geral que Sandra, Macedo já era professor do CECS há seis anos e estava há poucos meses como diretor-geral em outra escola da cidade. Os dois diretores-adjuntos também deixaram a direção com a exoneração de Sandra, substituídos por professoras que, como Macedo - e ao contrário da antiga equipe-, já eram do CECS, eram "da casa", como se dizia na escola.

$\mathrm{O}$ anúncio da nova Direção provocou reações de satisfação por parte de professores e alunos. Na sala dos docentes, Macedo foi parabenizado por seus colegas com abraços e apertos de mão. Um deles gritou "Habemus papam!", fazendo os demais rirem. O clima era de euforia com a chegada do novo diretor-geral. A mais antiga professora da escola, falou: "agora vai melhorar, botaram um dos nossos". $\mathrm{Na}$ primeira aula a que assisti depois de anunciada a nova Direção, a docente de geografia entrou em sala visivelmente entusiasmada. Após cumprimentar a turma, foi imediatamente para o quadro, onde escreveu as seguintes frases: "Sob nova direção. Prata da casa. I am happy [Eu estou feliz]”. Logo depois, virou-se para os estudantes e disse: "Estamos com sorte". Ficou durante alguns minutos falando sobre os professores escolhidos para os cargos de direção, dizendo-se otimista com tal escolha.

No mesmo dia em que assumiram, os diretores passaram em todas as salas de aula avisando às turmas sobre a mudança no comando da escola. Depois que Macedo anunciava que seria o novo diretor, os alunos aplaudiam e davam gritos de comemoração - "uhull”. Um professor que tinha entrado há poucos meses na escola, comentou o episódio comigo: "Impressionante. Todos os alunos aplaudindo. Não era um ou outro grupo não, todos”.

Perguntei aos estudantes por que eles haviam aplaudido o diretor. Dayane respondeu que ele era um professor que dava aula muito bem; Luana disse que as aulas dele eram "ótimas". Dayane e Luana eram duas alunas com perfis bem distintos. Luana era considerada uma "excelente aluna" pelos professores e tida como "cdf” por alguns de seus colegas. Já Dayane, segundo os docentes, era uma estudante "difícil", que já tinha se envolvido em brigas na escola com colegas e professores. Ambas, entretanto, mostravam-se satisfeitas com a escolha do novo diretor.

Também pedi a Macedo que explicasse a razão de ele ter sido indicado para assumir a escola e por que considerava que tinha sido aplaudido pelos alunos. Sobre sua chegada à instituição, falou que há algum tempo o CECS já vinha numa "decadência” e que sua indicação foi apenas o resultado desse processo. Segundo ele, a Secretaria interveio quando "viu que tinha uma confusão, um problema". Falou que "na verdade, a gente entrou como interventor". Em relação aos aplausos, justificava-os com o argumento de que já eram professores da escola assumindo a Direção: “a gente é de dentro, estava aqui há bastante tempo, tinha uma empatia com os alunos".

7 Galeno (2011) e Gomes (2012), em etnografias de escolas no Rio de janeiro, também acompanharam in loco situações de "intervenção" da SEEDUC. 
O contraste entre os dois diretores também me foi descrito pelo docente de sociologia. Ele disse que Macedo era um diretor popular e que a própria Secretaria tem os perfis de dirigentes para as escolas. A fala do professor alerta para a existência de distintas formas de legitimidade que são reconhecidas nos diretores e que serviriam de critério para alocá-los nas diferentes escolas, de acordo com a conjuntura de cada uma, o que corrobora o argumento de Maggie e Prado (2014) sobre a presença de ao menos duas culturas de gestão identificadas em escolas do Rio de Janeiro. Para as autoras, na cultura de gestão burocrático-racional, os gestores seguem as ordenações jurídicas, valorizam o mérito e buscam resultados positivos nas avaliações externas; já na cultura de gestão carismática, há uma concepção prévia de que o ensino não é para todos, os melhores alunos recebem atenção diferenciada e a relação com as instâncias superiores são conflituosas.

Uma das estratégias que Macedo adotou para tentar mudar a imagem da escola foi acrescentar ao logotipo do CECS o prefixo "novo", seguindo uma orientação dada pela Secretaria de Educação. A foto de exibição no perfil da escola no Facebook trazia a alteração, com a inscrição “Novo CECS”. A direção, por intermédio do Facebook, começou uma comunicação intensa pela internet com os alunos. Além de publicar diariamente informações no perfil da escola, controlado pelos dirigentes, Macedo e uma das diretoras adjuntas respondiam às frequentes perguntas e queixas que os estudantes faziam em um grupo fechado da escola na rede social. As respostas vinham acompanhas da assinatura "Novo CECS".

Os problemas não estavam resolvidos, mas a atitude dos alunos em relação a eles havia mudado. Em um dos dias logo depois da entrada de Macedo como diretor, vi uma aluna pedindo uma chave de fenda para a inspetora, que foi buscá-la e a entregou à menina. Quando cheguei ao corredor do $3^{\circ}$ ano, um grupo de estudantes, entre os quais a menina que pediu a ferramenta, lá estava consertando o bebedouro, que desde o início do ano não funcionava. De fato, parecia que eu estava em uma nova escola.

Até mesmo os mais inflamados alunos do grêmio, que iniciaram o processo de mobilização que resultaria na manifestação, passaram a apoiar a nova equipe de direção. Conversando com Bruno, um desses discentes com protagonismo, ouvi que os estudantes estavam tendo dificuldades para deliberar sobre quem participaria das reuniões propostas pela Secretaria de Educação, assim como para definir datas e horários possíveis. Havia alunos de duas escolas (CECS e LOTUS) para se fazer uma composição, além de que alguns estudavam em turnos diferentes, outros trabalhavam meio período (no turno em que não estavam em aula), dificultando o consenso entre eles. Segundo Bruno, tal situação acabou criando um desgaste entre os próprios colegas que estavam liderando as mobilizações.

Bruno contou que, apesar disso, os estudantes sentiam-se mais tranquilos com relação às reivindicações que faziam, pois viam como positiva a chegada dos professores da casa para assumir o comando da escola. As reuniões com a Secretaria acabaram não acontecendo e a agenda de reivindicações do grêmio estudantil também não foi levada adiante. O clima hostil dos alunos em relação à escola foi suplantado pelo entusiasmo que parecia acometer todos. Com seu carisma, o novo diretor-geral legitimava-se como a autoridade máxima da instituição. 


\section{Considerações Finais}

Neste artigo, busquei descrever etnograficamente a mobilização estudantil e suas consequências em uma escola da rede estadual do Rio de Janeiro, o que nos permite tecer considerações sobre como a participação dos estudantes na construção da vida pública tem ocorrido em âmbito escolar. Tal participação pressupõe uma forma de coordenação das ações coletivas, que deve ser objeto de análise juntamente com o estudo das dinâmicas que colaboram para sua efetiva realização, assim como o estudo das razões que predispõem os indivíduos a agirem conjuntamente em uma determinada situação.

O processo de mobilização foi liderado por alunos vinculados ao grêmio estudantil da escola. Embora houvesse um descontentamento de grande parte dos estudantes com as condições da instituição, foi um pequeno grupo do grêmio que iniciou a mobilização, convocando o restante dos discentes, buscando apoio dos professores, contatando órgãos da imprensa e fazendo os preparativos necessários para o dia da manifestação. Nesse sentido, o grêmio estudantil cumpriu um papel fundamental na atividade de socialização política dos demais estudantes, reforçando a seus colegas como as condições da escola não eram dignas da educação a que tinham direito e mobilizando-os para que participassem do protesto.

A falta de canais institucionais de interlocução dos alunos com diretores, professores e demais funcionários e a naturalização por estes três últimos dos problemas existentes na escola foram razões determinantes para que a mobilização dos estudantes resultasse na manifestação de rua. $\mathrm{O}$ diálogo com a direção foi praticamente inexistente. Até o último momento, a equipe dirigente tentou evitar o protesto, assim como os membros da Secretaria de Educação. Estes receberam os estudantes para uma "conversa", mas a ocasião foi marcada pelo confronto entre os discentes e os membros da Secretaria, sem que a agenda de reivindicações fosse atendida, sendo muitas vezes desqualificada.

O desencorajamento e a censura às mobilizações estudantis por melhorias nas escolas ocorrem em grande medida pela naturalização das condições desiguais de acesso a uma educação de qualidade. Tais condições provocam, por exemplo, uma disputa dos pais para conseguirem matricular seus filhos em certas instituições de ensino públicas que se diferenciam das demais em termos de qualidade (Rosistolato 2015) e fazem com que algumas escolas federais e técnicas (como o Colégio Pedro II e o Centro Federal de Educação Tecnológica Celso Suckow da Fonseca - Cefet, no Rio de Janeiro) realizem concurso de admissão visando a selecionar seu alunado.

Este texto não tratou apenas da mobilização, mas também do processo de desmobilização dos estudantes. Se a mobilização exige uma concertação das ações com vistas a um objetivo consciente, a desmobilização é reveladora das estratégias de agências estatais para garantir a subordinação. No caso analisado, a Secretaria de Educação recebeu alguns estudantes, ouviu suas queixas e prometeu fazer reuniões periódicas para discutir os problemas identificados nas escolas. A requisição feita pela Secretaria aos discentes para que discutissem entre si as datas e quem participaria das reuniões criou uma divergência entre eles, resultando na não realização dos encontros prometidos.

Apesar da proposta das reuniões, cujo objetivo evidente foi protelar uma discussão sobre as pautas levadas pelos manifestantes, a Secretaria já planejava outra medida não anunciada aos estudantes, 
uma "intervenção" na escola. A intervenção substituiu a direção, colocando uma nova equipe formada por professores populares da instituição, considerados da casa, sem que tenha havido qualquer tipo de consulta entre os docentes e os estudantes. O clima de insatisfação geral que dominava os espaços da instituição seria sublimado com o anúncio da nova equipe da direção, os "interventores", ocorrido três dias depois da manifestação dos alunos.

O fato de Macedo e as duas diretoras-adjuntas serem professores do CECS era claramente um fator diferencial na boa receptividade que tiveram quando assumiram. Ser da casa, alguém de dentro, era algo valorizado pelo público da escola, sobretudo os docentes, cujas falas exaltavam essa característica comum aos três. Tal atributo foi aproveitado estrategicamente pela Secretaria de Educação para arrefecer os ânimos na escola e desmobilizar os estudantes, o que de fato acabou ocorrendo.

Este estudo nos coloca, assim, um alerta para os processos de mobilização em curso na sociedade brasileira, especialmente aqueles oriundos de contextos escolares, considerando o atual momento de efervescência de discursos e valores antidemocráticos. Ao mesmo tempo em que mobilizações coletivas, tal qual manifestações de rua, são um recurso básico para a reivindicação de direitos, elas têm sido usadas para produzir ou validar práticas de gestão autoritárias e verticais, como a "intervenção" na escola analisada, as quais são justificadas e legitimadas em nome do restabelecimento da ordem. Não é demais lembrar que, nos últimos anos, vimos assistindo periodicamente no Brasil a manifestações de rua demandando uma nova intervenção militar, assim como a projetos de militarização da educação que já têm sido implementados (Castro 2016; Filpo et al. 2019).

Para finalizar nossa análise, é preciso colocar em discussão mais detidamente as motivações que têm dado origem às mobilizações estudantis. Tais razões nos permitem tecer considerações mais abrangentes sobre o exercício dos direitos de cidadania no Brasil e, mais especificamente, sobre o direito à educação. É possível identificar dois problemas mais gerais presentes na agenda de reivindicações dos estudantes que acompanhei em campo: o tratamento recebido pela equipe técnico-pedagógica e a precariedade de pessoal e das instalações da escola.

Além da falta de canais de diálogo, como já mencionamos, os estudantes queixavam-se constantemente do tratamento dispensado a eles por parte da equipe técnico-pedagógica. Eram frequentes as falas reclamando da "falta de respeito" quando lidavam com os funcionários da escola. Nesse sentido, as queixas dos alunos - e também dos pais - remetiam-se constantemente à questão da animalidade, onde se enfatizava que eles estavam sendo tratados como "bichos" e não como "gente".

A demanda por respeito reivindicada pelos estudantes está associada também com as condições de precariedade das instalações da escola, além da falta de professores, que fazia com que diariamente as turmas ficassem sem aula de alguma disciplina. Essas eram indubitavelmente as maiores fontes da indignação no cotidiano escolar. As más condições das salas de aula, muitas das quais sem carteiras suficientes, superlotadas, com ventiladores quebrados, instalações elétricas com fios aparentes e desencapados, paredes pichadas e descascando eram as mais ressaltadas no que diz respeito às críticas sobre as instalações.

Tal situação era vivida pelos estudantes como uma desconsideração de sua dignidade na condição de futuros adultos cidadãos. Isso fica bem expresso nos cartazes que levavam com dizeres como 
"Na sala de aula é que se muda uma nação" e "Aos que pensam que somos palhaços, lembrem-se que somos o futuro desse país". Portando narizes de palhaço, os discentes chamavam atenção para a falta de seriedade com que eram tratados, estando sujeitos àquelas condições de precariedade na instituição a que se atribui formalmente o papel de formação para a cidadania.

A animalidade, a demanda por respeito, o estudante como palhaço, todos esses dados revelam o caráter humilhante que a experiência escolar adquiria para os alunos, o que outras pesquisas tratando do ambiente da escola já identificaram (Caputo 2012; Miranda 2015; Maia, Miranda 2017; Petrosillo 2016). Segundo Dominique Vidal (2003: 281), sentimentos como respeito e humilhação são cada vez mais comuns na vida social e política e "exprimem uma reivindicação de reconhecimento no cerne da reflexão contemporânea sobre a cidadania democrática moderna”.

A reação por parte de setores historicamente subalternos nesse cenário de desigualdade e de injustiças no acesso a direitos no Brasil é o que Holston (2013) tem chamado de "cidadania insurgente". $\mathrm{O}$ autor argumenta que as grandes cidades brasileiras se tornaram, nas últimas décadas, foco de manifestações protagonizadas por novos atores políticos, que passaram a questionar regimes de privilégios em diferentes esferas da sociedade, pondo em xeque um modelo de "cidadania diferenciada" vigente no país. As mobilizações estudantis podem ser compreendidas como parte desse processo de emergência de uma "cidadania insurgente", levada a cabo por adolescentes e jovens majoritariamente excluídos de uma educação de qualidade. Pode-se dizer que os estudantes, sobretudo os secundaristas, tornaram-se na última década atores políticos fundamentais para se compreender essa insurgência cidadã no Brasil.

Iniciei este trabalho chamando atenção para o fato de que mobilizações coletivas oriundas de contextos escolares haviam emergido de modo significativo na última década no Brasil. Porém, para os pesquisadores de temas educacionais em particular e para a sociedade brasileira de modo geral, ainda é necessário qualificar melhor o que essas lutas por educação tentam exprimir.

Ortellado (2016), por exemplo, sugeriu que as ocupações de estudantes secundaristas de 2016 foram "a primeira flor de junho", ou seja, o primeiro desdobramento das manifestações de rua que tomaram o país em junho de 2013 e que elas ao mesmo tempo aspiravam e promoviam, entre outras coisas, uma nova dinâmica das aulas e relações entre professores, estudantes e gestores baseadas em processos decisórios horizontais. Concordo inteiramente com a filiação entre os movimentos de 2013 e 2016, mas não vejo evidências empíricas suficientes para apoiar a tese do autor sobre as aspirações a que se visava e, menos ainda, sobre os efeitos permanentes de tais aspirações na rede pública de ensino.

Nesse sentido, permaneço cético com conclusões como essa, que veem nas mobilizações estudantis (como no caso das ocupações) um sinal de que os estudantes querem novas formas de aprender, uma pedagogia alternativa ou espaços de aprendizado inovadores. Creio que tudo isso seria positivo para o sistema de ensino brasileiro, mas não parece ser a razão pela qual os discentes têm se mobilizado na grande maioria das vezes. Essa tese conforta nossas posições progressistas em relação às formas "tradicionais" de aprender, fazendo de nossos estudantes discípulos e entusiastas de uma pedagogia crítica que gostaríamos de ver implementada. No entanto, considerando as demandas das mobilizações estudantis que pudemos acompanhar, tal conclusão soa forçada, indo além do que os dados empíricos sugerem. 
Esse tipo de interpretação minimiza (quando não ignora, sumariamente) reivindicações por um tratamento uniforme, num país em que o tratamento diferenciado dos cidadãos por parte do poder público é socialmente e, em muitos casos, juridicamente o padrão desde a criação de nosso Estado-nação (DaMatta 1997; Cardoso de Oliveira 2011), reproduzindo desigualdades estruturais da sociedade brasileira. Assim, como Cardoso de Oliveira (2002) argumentou, na conformação do nosso precário "mundo cívico", diferenças de status entre os sujeitos incidem sobre os direitos de cidadania, como é o caso do direito à educação. Isso faz com que o nosso sistema de ensino transforme o acesso à educação de qualidade, como a possibilidade de frequentar uma "boa escola", em privilégios educacionais (Guedes, Kant de Lima 2019). É importante destacar que o componente central das mobilizações estudantis é a busca do gozo pleno de um direito social básico de cidadania.

Com a crescente valorização das mobilizações estudantis e da escola pública por camadas mais amplas da sociedade, como ocorreu no caso das ocupações dos secundaristas em 2016, temos a oportunidade (e a responsabilidade) como cientistas sociais de sublinharmos a distância que ainda separa essas instituições das particulares, assim como de fornecer subsídios a políticas educacionais que garantam a mesma qualidade de ensino para todas as unidades da rede estatal, as quais permanecem muito diferenciadas entre si, como atestam periodicamente os resultados dos exames de avaliação educacional nacionais e estaduais. Se praticamente universalizamos o acesso à educação básica, ainda estamos distantes de universalizarmos a educação de qualidade, como nos chamam atenção as manifestações de estudantes que testemunhamos.

No livro The decent society, o filósofo Avishai Margalit (1998) elabora o conceito de "sociedade decente", a partir de uma discussão sobre a humilhação e as demais formas de desumanização que provocam sentimentos imediatos de marginalização e exclusão social. Margalit propõe que uma "sociedade decente" seria aquela em que as instituições não humilhassem seus cidadãos, tratando-os com dignidade, independentemente de seus traços sociais. As mobilizações estudantis contemporâneas no Brasil nos mostram que há uma insurgência dos estudantes contra condições educacionais extremamente desiguais e, muitas vezes, humilhantes. Não se está em busca necessariamente de uma escola inovadora ou de métodos de aprendizagem alternativos, mas basicamente de uma escola que ofereça condições dignas de educação, uma escola decente.

Bóris Maia é Doutor em Antropologia pela Universidade Federal Fluminense (UFF), Professor Substituto do Departamento de Antropologia da UFF e Bolsista de Pós-Doutorado da Fundação de Amparo à Pesquisa do Estado do Rio de Janeiro (FAPERJ). 


\section{REFERÊNCIAS BIBLIOGRÁFICAS}

Barbosa, Fernanda S. e Ceres K Brum. 2018. "O vazio ocupa um espaço imenso: ocupações secundaristas e as habilidades necessárias para se mover na crise". Cadernos de Campo: Revista de Ciências Sociais 25: 245-268. Disponível em: https://periodicos.fclar.unesp.br/cadernos/article/ view/11542/8134.

Campos, Antonia M., Jonas Medeiros e Márcio M Ribeiro. 2016. 256. São Paulo: Veneta.

Caputo, Stela G. 2012. Educação nos terreiros: como a escola se relaciona com as crianças de candomblé. Rio de Janeiro: Pallas.

Cardoso de Oliveira, Luís R. 2002. Direito legal e insulto moral: dilemas da cidadania no Brasil, Quebec e EUA. Rio de Janeiro: Relume Dumará.

Cardoso de Oliveira, Luís R. 2011. "Concepções de Igualdade e Cidadania”. Contemporânea - Revista de Sociologia da UFSCar 1: 35-48. Disponível em: <http://www.contemporanea.ufscar.br/index. $\mathrm{php/contemporanea/article/view/19/4>.}$

Carvalho, Isabel. C. M., Chantal Medaets e Nadège Mezie. 2019. “'Uma aula assim muito forte': aprendizagem, escola e ritual em tempos de ocupação”. Revista Psicologia Política 19(45): 244-260. Disponível em: http://pepsic.bvsalud.org/scielo.php?script=sci_arttext\&pid=S1519-549X2019000200008.

Castro, Nicholas M. B. de. 2016. "Pedagógico" e "disciplinar": o militarismo como prática de governo na educação pública do Estado de Goiás. Dissertação de Mestrado. Programa de Pós-Graduação em Antropologia Social, Universidade de Brasília. Disponível em: <https://repositorio.unb.br/bitstream/10482/22204/1/2016_NicholasMoreiraBorgesdeCastro.pdf $>$.

Catini, Carolina de R. e Gustavo M. de C. Mello 2016. "Escolas de Luta: educação política”. Educação e Sociedade 37(137): 1177-1202. doi: https://doi.org/10.1590/es0101-73302016163403

Cefaï, Daniel. 2002. “Qu' est-ce qu'une arène publique? Quelque pistes pour une perspective pragmatiste”. Pp. 51-82 in L'héritage du pragmatisme, ed. D. Cefaï e I. Joseph. La Tour d'Aigues: Éditions de l'Aube.

Cefaï, Daniel. 2007. Pourquoi se mobilise-t-on? Les théories de l'action collective. Paris: Lectures, Les livres.

Corti, Ana Paula. de O., Maria Carla Corrochano \& José A. da Silva. 2016. “'Ocupar e resistir’: a insurreição dos estudantes paulistas”. Educação \& Sociedade 37(137): 1159-1176. doi: http://dx.doi. org/10.1590/es0101-73302016167337 
DaMatta, Roberto. 1997. A casa \& a rua: espaço, cidadania, mulher e morte no Brasil. 5. ed. Rio de Janeiro: Rocco.

Filpo, Klever P. L. et al. 2019. "Violência escolar e militarização das escolas: reflexões a partir de uma pesquisa de campo em Petrópolis, RJ”. In: Administração de Conflitos no Espaço Escolar: estudos interdisciplinares, org. B. Maia, K. Filpo e M. Verissimo. Rio de Janeiro: Autografia.

Galeno, Sabrina. 2011. Uma escola de luta: análise dos significados da educação em um estudo de drama social. Rio de Janeiro: 7 Letras.

Gohn, Maria da G. 2017. Manifestaçôes e protestos no Brasil: correntes e contracorrentes na atualidade. São Paulo: Cortez Editora.

Gomes, Raquel F. R. 2012. Ainda somos os mesmos: classificação, organização e ethos escolar. Dissertação de Mestrado. Programa de Pós-Graduação em Sociologia e Antropologia, Universidade Federal do Rio de Janeiro.

Guedes, Simoni L. e Edilson M. A. da Silva. 2019. "O segundo sequestro do verde e amarelo: futebol, política e símbolos nacionais”. Alheteia 3: 73-89. Disponível em: <http://www.memoria.fahce.unlp. edu.ar/art_revistas/pr.9691/pr.9691.pdf>.

Guedes, Simoni L. e Roberto Kant de Lima. 2019. “A educação como exclusão: direitos de cidadania e privilégios educacionais e jurídicos no Brasil". In: Administração de Conflitos no Espaço Escolar: estudos interdisciplinares, org. B. Maia, K. Filpo e M. Verissimo. Rio de Janeiro: Autografia.

Holston, James. 2013. Cidadania insurgente: disjunçôes da democracia e da modernidade no Brasil. São Paulo: Companhia das Letras.

Maggie, Yvonne e Ana P. Prado. 2014. "O que muda e o que permanece o mesmo nas escolas cariocas”. Pp 69-81 in Abordagens etnográficas sobre educação: adentrando os muros das escolas, org. S. Guedes e T. Cipiniuk. Niterói: Editora Alternativa.

Maia, Bóris. 2014. "Matéria de caderno: jocosidade e evitação nas aulas de ensino religioso em uma escola pública”. Pp. 163-183 in Abordagens etnográficas sobre educação: adentrando os muros das escolas, org. S. Guedes e T. Cipiniuk. Niterói: Editora Alternativa.

Maia, Bóris. 2019. Vida de escola: uma etnografia sobre carisma e autoridade na educação. Niterói: Eduff.

Maia, Bóris e Ana Paula M. Miranda. 2017. “Olhares, xingamentos e agressões físicas: a presença e a (in)visibilidade de conflitos referentes às relações de gênero em escolas públicas do Rio de Janeiro”. Horizontes Antropológicos 23: 177-202. doi: https://doi.org/10.1590/s0104-71832017000300007 
Margalit, Avishai. 1998. The decent society. Cambridge, Massachusetts; London, England: Harvard University Press.

Miranda, Ana Paula M. de. 2015. "Motivo presumido: sentimento": identidade religiosa e estigmatização escolar no Rio de Janeiro. Dilemas 1: 139-164. Disponível em: <https://revistas.ufrj.br/index. $\mathrm{php/dilemas/article/view/7319>.}$

Morais, Sérgio P., Denise N. de Sordi e Douglas G. Fávero. 2019. “Ocupação e contra ocupação de escolas públicas: o caráter político-educativo da mobilização coletiva”. Revista Trabalho Necessário 17(33): 138-161. doi: https://doi.org/10.22409/tn.17i33.p29372

Ortellado, Pablo. 2016. “A primeira flor de junho”. In: Escolas de luta. org. A. Campos, J. Medeiros \& M. Ribeiro. São Paulo: Veneta.

Petrosillo, Isabela R. 2016. Esse nu tem endereço: o caráter humilhante da nudez e da sexualidade feminina em duas escolas públicas. Dissertação de Mestrado. Programa de Pós-Graduação em Antropologia, Universidade Federal Fluminense. Disponível em: <http://ppgantropologia.sites.uff.br/ wp-content/uploads/sites/16/2016/07/Disserta\%C3\%A7\%C3\%A3o_Isabela_Petrosillo_2016_ PPGA_UFF.pdf $>$.

Pinheiro, Diógenes. 2017. "Escolas ocupadas no Rio de Janeiro em 2016: motivações e cotidiano”. Iluminuras 18(44): 265-283. doi: https://doi.org/10.22456/1984-1191.75746

Pinto, Vinícius C. 2014. "Aldeia resiste!": uma etnografia das estratégias politicas da "Aldeia Maracanã" no Rio de Janeiro. Dissertação de Mestrado. Universidade Federal Fluminense.

Resende, José M. 2008. A sociedade contra a escola?: a socialização politica escolar num contexto de incerteza. Lisboa: Instituto Piaget.

Rosistolato, Rodrigo P. R. 2015. "Choice and access to the best schools of Rio de Janeiro: a rite of passage". Vibrant 12: 380-416. doi: http://dx.doi.org/10.1590/1809-43412015v12n2p380

Sposito, Marília P. 1993. A ilusão fecunda: a luta por educação nos movimentos populares. São Paulo: Hucitec; Edusp.

Vidal, Dominique. 2003. "A linguagem do respeito: a experiência brasileira e o sentido da cidadania nas democracias modernas". Dados 46(2): 265-287. doi: http://dx.doi.org/10.1590/S001152582003000200003 


\title{
DO PROTESTO À INTERVENÇÃO: SOCIALIZAÇÃo POLÍTICA, CIDADANIA E INSURGÊNCIA EM MOBILIZAÇÕES ESTUDANTIS DE ESCOLAS PÚBLICAS
}

Resumo: Este artigo trata de mobilizações estudantis em escolas públicas, a partir de um caso acompanhado in loco no ano de 2013, baseado em trabalho de campo realizado pelo autor durante um ano letivo em uma escola pública do Estado do Rio de Janeiro. Com uma abordagem etnográfica, apresenta-se todo o processo de mobilização dos estudantes dessa instituição ao reivindicarem melhorias em seu contexto escolar. Analisa-se o processo de socialização política em jogo e o significado de tais demandas na atual conjuntura sociopolítica brasileira, tomando como referência a dinâmica que se estabeleceu ao longo do processo entre estudantes, professores, diretores e gestores, assim como o desfecho do caso analisado. Argumenta-se que as mobilizações estudantis colocam em questão o modelo de cidadania brasileiro, historicamente marcado pela desigualdade de direitos atribuídos a diferentes segmentos sociais.

Palavras-chave: Mobilização estudantil; Escola pública; Direito à educação; Cidadania; Etnografia escolar.

\section{FROM PROTEST TO INTERVENTION: POLITICAL SOCIALIZATION, CITIZENSHIP AND INSURGENCE IN STUDENT MOBILIZATIONS OF PUBLIC SCHOOLS}

\begin{abstract}
This paper deals with student mobilizations in public schools based on a case-study followed in loco in 2013, based on fieldwork carried out by the author during a school year at a public institution in Rio de Janeiro State, Brazil. With an ethnographic approach, it intends to present the process of mobilization of students in that school, who were claiming improvements in their institution. The analysis focuses on the process of political socialization at stake in the students' mobilization and the meaning of its demands in the current Brazilian socio-political context. It describes the dynamics established throughout the mobilization process among students, teachers, principals, and educational managers, as well as the outcome of the case under analysis. It argues that student mobilizations call into question the Brazilian citizenship model, which is historically characterized by the inequality of rights to different social segments.
\end{abstract}

Keywords: Student mobilizations; Public school; Right to education; Citizenship; Schooling ethnography.

RECEBIDO: $28 / 04 / 2020$

APROVADO: $21 / 12 / 2020$ 